\title{
Pengaruh Penggunaan Metode Pembelajaran Group Investigation Terhadap Literasi Keuangan Dengan Moderator Kecerdasan Emosional
}

\author{
Azizah Fauziyah $^{1}$, Disman $^{2}$, Kurjono ${ }^{3}$ \\ Program Studi Kewirausahaan, Kampus Daerah Tasikmalaya, Universitas Pendidikan Indonesia, Indonesia ${ }^{1}$ \\ Program Studi Pendidikan Ekonomi, FPEB, Universitas Pendidikan Indonesia, Bandung, Indonesia ${ }^{2}$ \\ Program Studi Pendidikan Akuntani, FPEB, Universitas Pendidikan Indonesia, Bandung, Indonesia ${ }^{3}$
}

\begin{abstract}
This study aims to improve students' financial literacy through group investigation learning methods on Introduction to Finance and Accounting subjects. In addition to the learning method, this study also takes the internal factors of students namely emotional quotient. The research method used is the design of quasi-experimental studies using factorial designs Between-Subject uses Two Ways ANOVA. The results of the study show that 1) there are differences in financial literacy in the class using the method of group investigation learning with the class using the discussion method; 2) there are differences in the increase in financial literacy of students with high, medium and low emotional quotient; and 3) there are interactions between group investigation distribution methods, emotional quotient, and financial literacy.
\end{abstract}

Keywords : Group Investigation; Emotional Quotient; Financial Literacy

\begin{abstract}
Abstrak. Penelitian ini bertujuan untuk meningkatkan literasi keuangan siswa melalui metode pembelajaran group investigation pada mata pelajaran Pengantar Keuangan dan Akuntansi.Selain dari metode pembelajaran, penelitian ini juga mengambil faktor internal siswa yaitu kecerdasan emosional.Metode penelitian yang digunakan yaitu dengan desain studi kuasi eksperimen memakai desain faktorial Between-Subject menggunakan Two Ways ANOVA. Hasil dari penelitian menunjukkan bahwa 1) terdapat perbedaan literasi keuangan pada kelas yang menggunakan metode pembelajaran group investigation dengan kelas yang menggunakan metode diskusi; 2) terdapat perbedaan peningkatan literasi keuangan siswa dengan kecerdasan emosional tinggi, sedang dan rendah; dan 3) terdapat interaksi antara metode pembelaran group investigation, kecerdasan emosional, dan literasi keuangan.
\end{abstract}

Kata Kunci : Group Investigation; Kecerdasan Emosional; Literasi Keuangan

Correspondence. azizahfauziyah@upi.edu' ${ }^{1}$, disman@upi.edu², kurjono@upi.edu³

History of article. Received: Oktober 2018, Revision: Januari 2019, Published: Maret 2019

\section{PENDAHULUAN}

Literasi keuangan merupakan salah satu alat efektif yang dapat meningkatkan perkembangan perekonomian. Saat ini, literasi keuangan dianggap lebih penting dibandingkan sebelumnya karena terdapat perubahan lingkungan ekonomi akibat adanya resesi global yang menyebabkan beberapa konsumen tidak dapat membuat keputusan keuangan yang sehat sehingga berakibat pada kesalahan pengambilan keputusan keuangan yang mengarah kepada tidak terciptanya stabilitas keuangan suatu negara (INFE, 2008:1; Nguyen, 2010:1; ljevleva \& Arefjevs, 2014:435; Assad, 2015:101-102).

Pentingnya literasi keuangan sebagai 1 dari 3 pilar yang terdapat dalam trilogi pemberdayaan konsumen membuat forum Organisation for Economic Cooperation and Development (OECD) rutin melakukan survey mengenai tingkat literasi keuangan dari negara-negara yang tergabung dalam G20 termasuk 5 negara dari kawasan ASEAN. Singapura memiliki tingkat literasi keuangan terbaik diantara 4 negara ASEAN lainny dengan tingkat literasi keuangan sebesar 98\%, sedangkan Indonesia hanya memiliki tingkat literasi keuangan sebesar 29,66\% (OECD, 2016). Masih rendahnya tingkat literasi keuangan Indonesia mengartikan bahwa tingkat melek finansial masyarakat Indonesia masih rendah dibandingkan dengan masyarakat negara ASEAN lainnya.

Dalam upaya peningkatan literasi keuangan, saat ini Otoritas Jasa Keuangan memilih menargetkan peningkatan literasi keuangan penduduk Indonesia pada usia produktif dibandingkan tingkatan usia lainnya (Rachman, 2015) dengan memprioritaskan strategi peningkatan tingkat literasi keuangan pada kalangan pelajar dan pekerja professional. Khusus pada tingkatan Sekolah Menengah Kejuruan (SMK) dimana siswa dipersiapkan untuk menjadi calon pegawai dan wiraswasta, pendidikan keuangan bukanlah berfokus pada tingkatan kognitifnya saja, melainkan berkaitan dengan perilaku, sikap, keterampilan dan pengambilan keputusan keuangan.Siswa SMK disiapkan untuk mengelola keuangan pribadi dan keluarga dan dapat membantu 
menyadari risiko keuangan sedini mungking meski belum memiliki penghasilan sendiri.

SMK Negeri 1 Bandung, memiliki tingkat literasi keuangan dengan kategori well rate sebesar 33,23\% dan mayoritas siswa berada pada kriteria sufficient literate, dimana siswa hanya memiliki pengetahuan serta keyakinan terhadap produk dan jasa keuangan terkait, tetapi belum mampu memiliki keterampilan berkaitan dengan pengelolaan keuangan.

Fenomena dimana pengetahuan keuangan lebih tinggi dibandingkan keterampilan pengelolaan keuangan menyadarkan kita semua bahwa suatu pendidikan keuangan tidak serta merta menghasilkan literasi keuangan yang baik. Dibutuhkan lebih dari sekedar pendidikan keuangan yang dapat dikembangkan melalui penggunaan metode pembelajaran yang dapat mengakomodasi interaksi antara guru dan siswa sehingga pembelajaran lebih bermakna.

John Dewey (1972) mengatakan bahwa suatu pengetahuan dibentuk berdasarkan pengalaman belajar sebelumnya sehingga proses pembelajaran akan lebih bermakna dan menghasilkan perilaku yang lebih tahan lama.

Penelitian ini bertujuan untuk melihat perbedaan literasi keuangan pada kelas eksperimen yang menggunakan metode pembelajaran group investigation dan literasi keuangan pada kelas kontrol yang menggunakan metode diskusi. Selain itu, penelitian ini bertujuan untuk melihat perbedaan literasi keuangan pada siswa dengan kecerdasan emosional tinggi, sedang dan rendah; dan akhirnya dalam penelitian ini akan dilihat interaksi antara metode pembelajaran group investigation, kecerdasan emosional dan literasi keuangan

\section{KERANGKA PENELITIAN \& HIPOTESIS}

Hasil dari berbagai penelitian, tingkat literasi keuangan siswa dipengaruhi oleh banyak factor, namun terdapat faktor yang mengarah kepada peningkatan perilaku keuangan yang sudah terbentuk sebelumnya melalui pengetahuan dan pengalaman siswa dalam proses pembelajaran (Hogarth, 2002:15). Meski begitu, proses pembelajaran melalui pendidikan keuangan tidak akan menghasilkan perilaku keuangan begitu saja.

Selain komponen kebijakan, kurikulum, kondisi guru, kondisi siswa, dan isi materi yang disampaikan, hal terpenting bagi pendidikan keuangan adalah adanya metode penyampaian pendidikan keuangan yang akan menginformasikan perubahan positif dalam literasi keuangan dan perilaku keuangan di kalangan remaja (Totenhagen et al, 2014:167).
Selama ini, metode pembelajaran yang digunakan untuk membantu meningkatkan literasi keuangan melalui pendidikan keuangan diantaranya permainan didaktis, pendidikan dramatis, instruksi langsung, kunjungan ke lembaga keuangan terkait serta pelatihan langsung dari instuktur keuangan yang terpercaya (Walstad et al, 2010:337; Nguyen, 2013:13; Maurer, 2014:-; Opletalova, 2015:1177) yang hanya mampu meningkatkan pengetahuan keuangan, namun masih lemah dalam hal pengaplikasian pengetahuan dalam kehidupan sehari-hari. Dibutuhkan penggunaan metode pembelajaran modern yang mampu meningkatkan kreatifitas, inisiatif dan pengalaman terbaik dari siswa, salah satunya melalui metode pembelajaran studi kasus berdasarkan kehidupan sehari-hari.

Penggunaan metode group investigation dalam menginvestigasi studi kasus berdasarkan kehidupan sehari-hari dapat memberikan kesempatan seluasluasnya kepada siswa untuk terlibat langsung dan aktif dalam proses pembelajaran. Melalui penggunaan metode group investigation, siswa akan mendapatkan pengetahuan berdasarkan pengalaman yang akan memberikan dampak terbaik terhadap perilaku serta memberikan output pembelajaran kognitif yang mengarahkan kemampuan berpikir tingkat tinggi, kemampuan menganalisis, serta kemampuan evaluasi; serta output pembelajaran afektif berupa peningkatan sikap dan perilaku (Sharan \& Sharan, 1992:17; Shachar \& Sharan, 1994; Zingaro, 2008:1).

Untuk memberikan output yang optimal dari implementasi metode group investigation dibutuhkan kecerdasan emosional yang terdiri dari sifat inisiatif, kepercayaan diri, dan rasa tanggung jawab dari siswa. Secara teori, kecerdasan emosional sangat penting untuk perencanaan dan pengelolaan keuangan (Makunike, 2012:4; Braidfoot \& Swanson, 2013:11). Memiliki kecerdasan emosional yang tinggi merupakan salah satu cara yang paling optimal untuk mencapai ketenangan pikiran di sekitar uang yang dimiliki. Kecerdasan emosional keuangan tidak hanya mampu menyatukan proses pengambilan keputusan intutitif yang disengaja, namun juga memungkinkan kita untuk menyalurkan emosi kita menjadi hasil yang lebih produktif.

Berdasarkan kajian teoritis dan kerangka pemikiran di atas maka hipotesis yang diajukan dalam penelitian ini sebagai berikut:

1. Terdapat perbedaan literasi keuangan siswa pada kelas eksperimen yang menggunakan metode group investigation dengan kelas kontrol yang menggunakan metode diskusi.

2. Terdapat perbedaan peningkatan literasi keuangan siswa yang menggunakan metode group 
investigation pada siswa yang memiliki kecerdasan emosional tinggi, sedang dan rendah.

3. Terdapat interaksi antara metode group investigation, kecerdasan emosional, dan literasi keuangan siswa.

\section{METODE PENELITIAN}

Metode yang akan digunakan adalah eksperimen semu (quasi experiment) untuk mengetahui efek perlakuan (treatment). Penelitian ini akan menggunakan desain faktorial (factorial design) $3 \times 2$. Adapun variabel penelitiannya, $X_{1}$ : Teknik pembelajaran Group Investigation (variabel independen) sebagai treatment, $\mathrm{X}_{2}$ : Kecerdasan Emosional (Tinggi, Sedang dan Rendah) merupakan variabel independen sebagai faktor, $Y$ : Literasi Keuangan sebagai variabel dependen.

Tabel 1.Desain Eksperimen Faktorial

\begin{tabular}{cccc}
\hline \multirow{2}{*}{$\begin{array}{c}\text { Faktor } \\
\text { (B) }\end{array}$} & \multicolumn{2}{c}{ Metode(A) } \\
\cline { 3 - 4 } & Tinggi $\left(\mathrm{B}_{1}\right)$ & Group Investigation \\
(Kelas eksperimen)(A1) & $\begin{array}{c}\text { Diskusi } \\
\text { (Kelas } \\
\text { Kontrol)(A2) }\end{array}$ \\
\hline Kecerdasan & Sedang $\left(\mathrm{B}_{2}\right)$ & $\mathrm{A} 1 \mathrm{~B} 1$ & $\mathrm{~A} 2 \mathrm{~B} 1$ \\
Emosional & A1B3 & A2B2 \\
& Rendah $\left(\mathrm{B}_{3}\right)$ & A2B3 \\
\hline
\end{tabular}

Populasi dalam penelitian ini adalah seluruh siswa SMK Negeri 1 Bandung kelas XI program keahlian Pemasaran (PS) sebanyak 141 siswa yang terdiri dari 4 kelas yaitu XI-PS 1 dengan jumlah siswa 35, XI-PS 2 dengan jumlah siswa 30, XI-PS 3 dengan jumlah siswa 34 dan XI-PS 4 dengan jumlah siswa 35. Pemilihan populasi didasari pada kompetensi dasar yang berkaitan dengan kurikulum pendidikan keuangan yang ada di kelas XI Pemasaran dengan kompetensi dasar Menjelaskan dan Mengklasifikasi Sistem dan Prsedur Penggunaan Uang. Subjek penelitian akan dipilih sebanyak dua kelas (kelas ekperimen dan kelas kontrol) dari populasi yang ada.

\section{HASIL DAN PEMBAHASAN}

Hasil penelitian menunjukkan bahwa pada aspek kecerdasan emosional Kelas XI PS 2 memiliki kecerdasan emosional yang lebih rendah dibandingkan Kelas XI PS 3. Berikut disajikan dalam Gambar 1. dibawah ini :

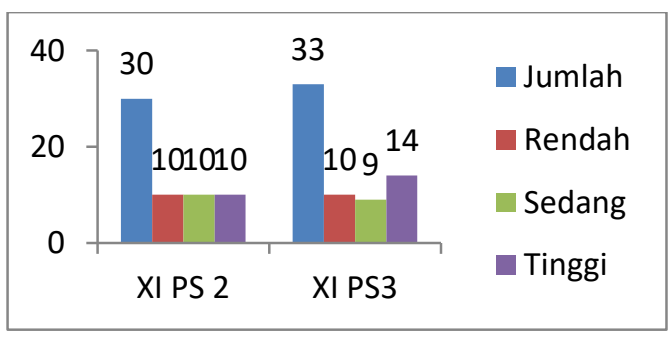

Sumber : data diolah (2017)

\section{Gambar 1. Kriteria Kecerdasan Emosional Siswa}

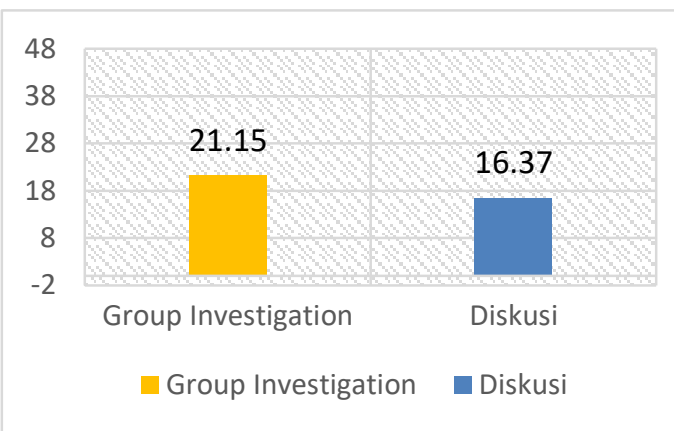

Sumber :data diolah (2017)

Gambar 2. Perbedaan Literasi Keuangan Siswa

Pengujian hipotesis menggunakan Analisys of Variance Between Subject Design. Anova dalam penelitian eksperimen ini digunakan untuk menguji main dan interaction effect satu atau lebih variabel independen nonmetrik atau kategorial yang kategorinya lebih dari dua terhadap satu variabel independen metrik (interval, rasio).Variabel independen disebut dengan faktor dan penelitian ini melibatkan 2 faktor yaitu Metode dan Kecerdasan Emosional. Berikut ini adalah hasil dari perhitungan Anova Between Subject Desain.

Tabel 2. Hasil Pengujian Anova Between Subject Design

\begin{tabular}{crr}
\hline Source & \multicolumn{1}{c}{ F } & \multicolumn{1}{c}{ Sig. } \\
\hline Corrected Model & 62.630 & .000 \\
Intercept & 14197.543 & .000 \\
Metode & 283.320 & .000 \\
Kecerdasan Emosional & 208.972 & .000 \\
Metode * Kecerdasan Emosional & 32.648 & .015 \\
Error & & \\
Total & & \\
Corrected Total & &
\end{tabular}

Berdasarkan hasil pengujian Anova Between Subject Design nilai signifikasi $<0,05$ sehingga ketiga hipotesis yang diajukan diterima, dan interaksi antara metode pembelajaran dengan kecerdasan emosional dalam kaitannya dengan literasi keuangan siswa terlihat jelas dalam gambar profil plot estimated means of Literasi Keuangan Siswa berikut ini. 


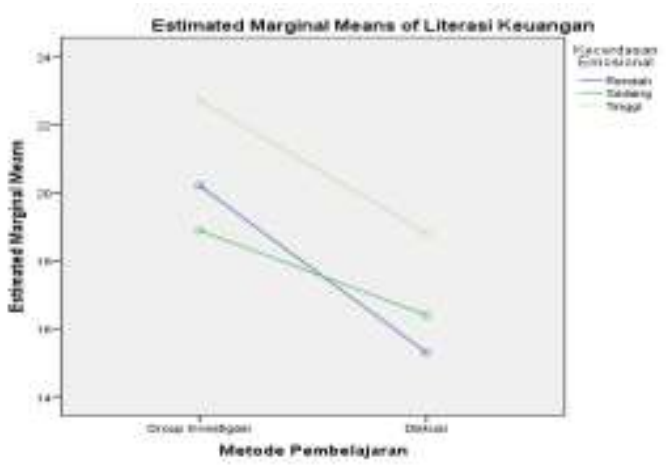

Sumber :data diolah (2017)

Gambar 3. Profile Plots Interaksi Metode dan Kecerdasan Emosional

Kelompok siswa yang menggunakan metode group investigation mempunyai rata-rata lebih tinggi dibandingkan dengan kelompok siswa yang menggunakan metode pembelajaran konvensional (diskusi). Artinya, metode group investigation lebih efektif dibandingkan dengan metode diskusi dalam meningkatkan literasi keuangan siswa.

Suatu hal yang lumrah terjadi jika hasil belajar menjadi lebih baik setelah kegiatan pembelajaran selesai dilakukan.Baik kelas yang menggunakan metode pembelajaran group investigation maupun kelas yang menggunakan metode diskusi, keduanya sama-sama mengalami peningkatan literasi keuangan.

Kedua kelas sama-sama mengalami peningkatan literasi keuangan karena kedua kelas sama-sama mendapatkan alokasi waktu pembelajaran yang sama yakni 8 jam pelajaran (4 kali pertemuan). Menurut penelitian Berheim \& Garret (2003:1488), waktu penyampaian pendidikan keuangan terbaik \pm dalam rentang waktu 8-12 jam pelajaran. Meski penelitian yang dilakukan oleh Fox, Bartholomar \& Lee (2005:197) menyatakan bahwa metode penyampaian pendidikan keuangan terbaik terdiri dari kegiatan seminar, konsultasi dengan seorang professional dan pemberian materi yang dilakukan oleh pekerja keuangan langsung, namun seluruh metode penyampaian tersebut tidak akan memberikan efek berarti jika hanya dilakukan dalam waktu yang singkat (Kezar, 2010; Jang, Hahn dan Park, 2014:22; Fernandes, Lynch Jr. \& Netemeyer , 2013:4)

Perbedaan penggunaan metode pembelajaran yang digunakan tentu akan menghasilkan literasi keuangan yang berbeda (Pang, 2008:659). Berdasarkan Gambar 2, kelas yang menggunakan metode pembelajaran group investigation dengan metode diskusi dimana metode pembelajaran group investigation meningkatkan literasi keuangan lebih baik dibandingkan kelas yang menggunakan metode diskusi. Perbedaan tersebut menggambarkan bahwa terdapat perbedaan pengaruh antara kedua metode tersebut, salah satunya diakibatkan karena adanya perbedaan sintak/langkah-langkah pada masingmasing metode.

Pertama, perbedaan pengaruh berkaitan dengan perbedaan penentuan anggota kelompok dimana metode pembelajaran group investigation membagi anggota kelompok secara acak sehingga kelompok yang terbentuk bersifat heterogen, baik dari segi pendidikan maupun dari perbedaan latar belakang keluarga (perbedaan pendidikan orang tua, perbedaan pekerjaan orang tua). Melalui pembentukan kelompok yang heterogen, masingmasing kelompok akan memiliki anggota yang memiliki pendidikan dan latar belakang keluarga yang baik dalam menyampaikan pendidikan keuangan dan akan menyampaikan pengetahuan yang dimilikinya kepada anggota dalam kelompoknya.

Perbedaan pengaruh juga terletak pada pemilihan topik diskusi yang beragam. Dengan topik diskusi yang lebih beragam dibandingkan metode diskusi, metode pembelajaran group investigation memiliki kelebihan pengalaman pendidikan keuangan yang lebih beragam. Suatu pendidikan keuangan, jika hanya didemonstrasikan atau diilustrasikan dengan topik yang sama, maka efek yang akan dihasilkan bersifat tidak konsisten (Anthes \& Most, 2000:). Penelitian sebelumnya yang dilakukan oleh Frijns, Gilbert \& Rad (2014:130) menyebutkan bahwa pendidikan keuangan yang sukses adalah pendidikan keuangan berdasarkan pengalaman dan studi kasus yang diberikan sebaiknya berupa kasus yang ada dalam kehidupan sehari-hari. Sejalan dengan grand theory pembentuk metode pembelajaran group investigation yang merupakan rumpun kontruktivisme dari John Dewey (1972) yang menyebutkan bahwa proses pembentukan pengetahuan dan perilaku akan bertahan lebih lama jika dibentuk melalui pengalaman dalam kegiatan pembelajaran.

Adanya studi kasus pada kedua metode pembelajaran nyatanya menimbulkan perbedaan peningkatan literasi keuangan. Luksander et al (2014) mengatakan bahwa meski kedua metode sama-sama menggunakan studi kasus sebagai media pembelajaran, namun metode tradisional, dalam hal ini adalah metode diskusi hanya fokus pada pengetahuan saja, namun tidak dapat diaplikasikan dalam kehidupan nyata. Metode pembelajaran group investigation tidak hanya mampu mengontrol perilaku siswa, namun memberikan kendali pada siswa untuk menggali pengetahuan lebih banyak dibandingkan metode pembelajaran lainnya. 
Berdasarkan hasil uji hipotesis yang dilakukan menunjukkan bahwa hipotesis kedua mengenai kecerdasan emosional memperoleh nilai $F=32,648$ dan $p=0,000<0,05$ yang berarti bahwa hipotesis kedua diterima, bahwa terdapat perbedaan literasi keuangan siswa yang menggunakan metode pembelajaran group investigation dengan kecerdasan emosional tinggi, sedang dan rendah.

Hasil uji hipotesis tersebut menggambarkan bahwa kecerdasan emosional kelas eksperimen dan kelas kontrol berpengaruh terhadap literasi keuangan. Berdasarkan penelitian yang dilakukan di SMK Negeri 1 Bandung, diperoleh temuan bahwa kecerdasan emosional siswa kelas eksperimen lebih tinggi untuk kategori kecerdasan emosional tinggi dibandingkan dengan kelas kontrol dengan kategori kecerdasan emosional tinggi. Dengan demikian kecerdasan emosional dalam proses pembelajaran dapat meningkatkan kemampuan siswa untuk mengelola keuangan pribadi.

Makunike (2012:4) dan Braidfoot \& Swanson (2013:11) menyebutkan bahwa kecerdasan emosional sangat penting dalam perencanaan dan pengelolaan keuangan. Memiliki kecerdasan emosional yang tinggi merupakan salah satu cara yang paling optimal untuk mencapai ketenangan pikiran di sekitar uang yang dimiliki. Kecerdasan emosional keuangan tidak hanya mampu menyatukan proses pengambilan keputusan intuitif yang disengaja, namun juga memungkinkan kita untuk menyalurkan emosi kita menjadi hasil yang lebih produktif.

Pendapat dari penelitian terdahulu yang telah dijabarkan di atas tentu menjawab hasil penelitian, bahwa dalam meningkatkan literasi keuangan siswa selain melalui metode pembelajaran tidaklah cukup, akan tetapi diperlukan kecerdasan emosional pada diri siswa. Kecerdasan emosional siswa di dalam proses pembelajaran sangat penting bagi siswa dalam membentuk pemikiran yang akan membantu pengambilan keputusan keuangan yang rasional dan bertanggung jawab.

Berdasarkan hasil uji hipotesis ketiga mengenai interaksi metode pembelajaran dan kecerdasan emosional terhadal literasi keuangan, diperoleh nilai $F$ $=4,550$ dan $p=0,015<0,05$ artinya hipotesis ketiga diterima, bahwa terdapat interaksi metode pembelajaran group investigation dengan kecerdasan emosional terhadap literasi keuangan siswa dalam mata pelajaran Pengantar Akuntansi dan Keuangan Kompetensi Dasar Menjelaskan serta Mengklasifikasi Sistem dan Prosedur Penggunaan Uang.

Kecerdasan emosional merupakan faktor yang cukup krusial untuk meningkatkan kinerja baik dalam lingkungan bisnis maupun dalam lingkungan pendidikan. Seseorang dengan kemampuan emosional yang baik mampu mendorong keberhasilan karena dapat memenuhi keinginan dan kebutuhannya sendiri. Menurut penelitian yang dilakukan oleh Parker et.al (2004:163), kecerdasan emosional yang tinggi dapat meningkatkan tingginya keberhasilan siswa, terutama dari segi akademik. Pada tingkatan sekolah menengah, siswa memang dipersiapkan untuk memiliki kompetensi berdasarkan pengembangan pengetahuan dan teknologi yang ada di dunia kerja. Siswa sekolah menengah yang memiliki kemampuan sosial dan kecerdasan emosional yang tinggi akan menghasilkan performa akademik terbaik jika dibandingkan dengan siswa lainnya.

Hasil penelitian Parker et al (2004:163) didukung juga oleh hasil penelitian yang dilakukan oleh Petrides, Frederickson, \& Furnham (2004:276), yang menyatakan bahwa kecerdasan emosional mampu meningkatkan keseluruhan kinerja akademik siswa namun berpengaruh negatif terhadap perilaku yang menyimpang dan hanya dapat diterapkan pada mata pelajaran Matematika, Sains, dan Bahasa Inggris saja. Hal tersebut menjadikan hasil penelitian ini sebagai temuan terbaru dimana kecerdasan emosional mampu meningkatkan performa terbaik dalam mata pelajaran pengantar keuangan dan akuntansi, terutama dalam hal peningkatan perilaku keuangan.

Literasi keuangan bukan hanya berkaitan dengan pengetahuan dan perilaku keuangan saja.Melalui pengetahuan dan perilaku keuangan diharapkan siswa dapat mengambil keputusan keuangan yang lebih bertanggung jawab. Sandlin (2000) dan O'Connel (2008:10) mengatakan bahwa memiliki pengetahuan mengenai masalah keuangan memang merupakan hal yang penting, namun memiliki pengetahuan saja tidak dapat menjamin keputusan keuangan yang terbaik.Untuk meningkatkan kemampuan siswa dalam hal pengambilan keputusan keuangan, dibutuhkan kecerdasan emosional yang mampu menghindari potensi bahaya dan menahan alam bawah sadar siswa. Penelitian yang dilakukan oleh Sullivan (2011:1) menyebutkan melalui kecerdasan emosional, keputusan yang diambil akan berdasarkan masukan dari emosi sendiri serta mempertimbangkan tiap resiko dan manfaat. Hess \& Bagicalupo (2011:710), Harati (2013:2), dan Brown (2016:2) menambahkan bahwa seseorang yang tidak memiliki kecerdasan emosional tidak mampu membuat keputusan yang logis dan rasional.

Secara teori, kecerdasan emosional sangat penting untuk perencanaan dan pengelolaan keuangan (Makunike, 2012:4; Braidfoot \& Swanson, 2013:11). Memiliki kecerdasan emosional yang tinggi merupakan salah satu cara yang paling optimal untuk mencapai ketenangan pikiran di sekitar uang yang dimiliki. Kecerdasan emosional keuangan tidak hanya 
mampu menyatukan proses pengambilan keputusan intutitif yang disengaja, namun juga memungkinkan kita untuk menyalurkan emosi kita menjadi hasil yang lebih produktif.

Untuk itu, pengaruh penggunaan metode pembelajaran group investigation berdasarkan kecerdasan emosional terhadap literasi keuangan dalam mata pelajaran pengantar keuangan dan akuntansi menjadi salah satu faktor yang penting dalam usaha meningkatkankan literasi keuangan siswa.

\section{KESIMPULAN}

Berdasarkan latar belakang, penelitian, tujuan penelitian, hasil pengolahan data dan pembahasan hasil, kesimpulan dalam penelitian yaitu Terdapat perbedaan literasi keuangan siswa pada kelas eksperimen yang menggunakan metode pembelajaran group investigation dengan kelas kontrol yang menggunakan metode diskusi. Literasi keuangan siswa pada kelas yang menggunakan metode pembelajaran group investigation lebih tinggi dibandingkan dengan kelas yang menggunakan metode diskusi.

Terdapat perbedaan peningkatan literasi keuangan siswa yang menggunakan metode pembelajaran group investigation pada siswa yang memiliki kecerdasan emosional tinggi, sedang dan rendah. Siswa yang memiliki kecerdasan emosional yang tinggi memiliki tingkat literasi keuangan yang lebih tinggi dibandingkan dengan siswa yang memiliki kecerdasan emosional sedang dan rendah.

Terdapat interaksi antara metode pembelajaran group investigation, kecerdasan emosional, dan literasi keuangan siswa. Dengan demikian, dalam usaha untuk meningkatkan literasi keuangan siswa, selain penggunaan metode pembelajaran group investigation, diharapkan siswa memiliki kecerdasan emosional dengan tujuan mengoptimalkan perencanaan dan pengelolaan keuangan secara pribadi.

\section{REKOMENDASI}

Berdasarkan pada hasil hasil penelitian dan kesimpulan, maka rekomendasi kepada semua pihak yaitu Agar hasil literasi keuangan lebih optimal, sebaiknya dipersiapkan alokasi waktu yang memadai dalam penggunaan metode pembelajaran group investigation. Sarana dan prasarana selama kegiatan pembelajaran juga harus dipersiapkan untuk masingmasing kelas sehingga memiliki tingkat literasi keuangan yang sama antara satu kelas dengan kelas yang lainnya

Dibutuhkan banyaknya dan kualitas sumber informasi baik berbentuk cetak maupun berbentuk elektronik dapat disesuaikan dengan banyaknya siswa sehingga siswa dapat mendapatkan informasi yang relevan dengan kualitas sumber terbaik

Dibutuhkan peran serta guru, kepala sekolah dan orang tua siswa tetap diperlukan agar pencapaian literasi keuangan dapat menciptakan pengambilan keputusan keuangan yang lebih bertanggung jawab

Untuk siswa dengan hasil literasi keuangan yang rendah, maka diperlukan pengembangan dan penerapan metode pembelajaran yang lain yang mampu membantu meningkatkan literasi siswa, sedangkan untuk siswa dengan tingkat literasi keuangan yang sudah tinggi, maka perilaku pengelolaan keuangan dan pengambilan keputusan keuangan yang bertanggung jawab harus tetap dipertahankan meski siswa terebut sudah selesai menyelesaikan pendidikan formal

Untuk penelitian selanjutnya, peneliti lain disarankan untuk menggunakan metode pembelajaran lainnya sesuai dengan Kurikulum 2013 yang dapat membantu meningkatkan literasi keuangan. Peneliti lain sebaiknya menambah variabel moderator lainnya seperti kecerdasan intelektual dan kecerdasan spiritual yang dapat membantu memperkuat pengaruh suatu metode pembelajaran terhadap literasi keuangan. Selain itu, peneliti lain dapat mengembangkan metode pembelajaran lainnya yang dapat diterapkan pada tingkatan pendidikan lainnya.

\section{DAFTAR PUSTAKA}

Anthes, W. L. \& Most, B.W. 2000. Frozen in the Headlights: The Dynamics of Women and Money. Journal of Financial Planning, 13 (9): 130-142

Asaad, C.T., 2015. Financial literacy and financial behavior : Assessing knowledge and confidence. Financial Services Review 24, 205, 2015, pp 101-117.

Bernheim, B.D., Garrett,D.M., \& Maki, D.M. 2001. Education and Saving: The Long-Term Effects of High School Financial Curriculum Mandates. Journal of Public Economics, 80 (June): 436-466.

Braidfoot, R. \& Swanson, A.C. 2013.Emotional Intelligence of Financial Planners in Mediation. Review of Business and Finance Studies Vol. 4 No. 2. 
Brown. 2016. A Quantitative, Quasi-Experimental Study On Emotional Intelligence and Leadership Performance In The Financial Services Industry. Dissertation, University of Phoenix

Chen, H \& Volpe, R.P. 1998. An analysis of personal financial literacy among college students. Financial Service Review, 7(2), 107-128

Fernandes, Lynch, \& Netemeyer. 2013. The Effect of Financial Literacy and Financial Education on Downstrem Financial Behaviors. Child Finance International, 2013.

Fox, Bartholomar \& Lee. 2005. Building the Case for Financial Education. The Journal of Consumer Affairs Vol. 39, No. 1, 2005

Fijns, B., Gilbert, A., Rad, A.T. 2014. Learning by doing : the role of financial experience in financial literacy. Journal of Public Policy Vol 32, pp. 123-154.

Goleman, D. 2002. Emotional Intelligence. Jakarta: PT Gramedia Pustaka Utama.

Harati, L.W. 2013. Relationship Between Emotional Intelligence and Ethical Decision Making In Educational Leaders. Dissertation, Saint Louis University

Hess, J., Bacigalupo, A.C. 2011. Enhancing decisions and decision-making processes through the application of emotional intelligence skills. Management Decision Vol. 49 pp. 710-721.

Hogarth, J. 2002. Financial literacy and Family and Consumer Sciences. Journal of Family and Consumer Sciences, 94, 14-28.

Hogarth M, Hilgert M. 2002. Financial knowledge, experience and learning preferences: preliminary results form a new survey on financial literacy. Consume Interest Annu 48:1-7

Ijevleva, K.; Arefjevs, I. 2014.Analysis of the aggregate financial behavior of costumers using the transtheoretical model of change.Social and Behavioral Sciences $156 \mathrm{p}$. 435-438.Elsevier.

International Network on Financial Education (INFE). 2008. Financial Education in Schools. OECD.
Jang K., Hahn J., Park, H.J. 2014. Comparison of financial literacy bertween Korean and U.S. high school students.International Review of Economic Education Vol 16 p. 2238.Elsevier.

Kezar, A. 2010.Financial literacy, a key to success for low income students. The Chronicle of Higher Education.Retrieved from http://chronicle.com.

Makunike, T. 2012. Emotional intelligence in managing finances. New Zimbabwe.

Mandell, L. 2008. Financial Literacy of High School Students.Handbook of Consumer Finance Research.Springer.

Maurer, Trent W. 2014. Process-Oriented GuidedInquiry Learning in Financial Literacy Education. NC State University, Departement of 4-H Youth Development and Family \& Consumer Sciences

Nguyen, Kathy N. 2013. High School Senior's Financial Knowledge : The Impact of Financial Literacy Classes and Development Assets. Proquest, UMI No. 1542137.

Opletalova, Alena. 2015. Financial education and financial literacy in the Czech education system. Procedia Social and Behavioral Sciences 171 p. 1176 - 1184.Elsevier.

Otoritas Jasa Keuangan. 2015. Implementasi Strategi Nasional Literasi Keuangan Indonesia.

Parker, J. D. A., Summerfeldt, L. J., Hogan, M. J., \& Majeski, S. 2004. Emotional intelligence and academic success: Examining the transition from high school to university. Personality and Individual Differences, 36, 163-172.

Petrides, K. V., Frederickson, N., \& Furnham, A. 2004. The role of trait emotional intelligence in academic performance and deviant behavior at school. Personality and Individual Differences, 36, 277-293.

Rachman, V.. 2015. Tingkat Literasi Keuangan, OJK Bidik Usia Produktif. http://swa.co.id/swa/businessstrategy/tingkatkan-literasi-keuangan-ojkbidik-usia-produktif. Diunduh pada : 28 November 2016. 
Sharan \& Sharan. 1990. Group Investigation Expands Cooperative Learning. Journal of Educational Leadership p. $17-21$.

Sharan \& Sharan. 1992. Expanding Cooperative Learning Through Group Investigation. Teachers College Press, 1234 Amsterdam Avenue, New York, NY 10027 (\$37, cloth-ISBN-0-8077-3191-9; \$17.95, paperback-ISBN-0-8077-3190-0).

Sullivan, R. 2011. Deploying Financial Emotional Intelligence.Behavioral Finance.

Totenhagen et al. 2014. Youth Financial Literacy : A Review of Key Consideration and Promising Delivery Methods. Journal Family Economy Issues Vol. 36, pp. 167-191.

Walstad et al. 2010. The Effects of Financial Education on the Financial Knowledge of High School Students. The Journal of Consumer Affairs, Vol. 44, No. 2, 2010 ISSN 0022-0078.

Zingaro, D. 2008. Group investigation theory and practice. Ontorio: Institute for Studies in Education 